\title{
Small lymphocytic lymphoma in true trilineage hematopoietic tissue within heterotopic ossification in an enucleated blind painful eye: a case report
}

\author{
Alfredo Borgia ${ }^{1 *}$, Sofia Manara ${ }^{2}$, Monica Balzarotti ${ }^{2}$, Paolo Vinciguerra ${ }^{1}$ and Alessandra Di Maria ${ }^{1}$
}

\begin{abstract}
Background: The finding of hematological malignancies within bone marrow in heterotopic ossification has been reported only a handful of times previously in the literature. We described a case of true trilineage hematopoiesis in an excised area of heterotopic ossification from an enucleated blind painful eye.

Case presentation: A 70-year-old Caucasian man, positive for asymptomatic lymphoplasmacytic lymphoma, presented with a blind painful right eye in our ophthalmology department to evaluate enucleation bulbi. After enucleation, a histopathologic examination revealed the presence of intertrabecular infiltration in the metaplastic bone marrow of non-Hodgkin B lymphoma, with small lymphocytes, with similar characteristics to the already known disease.

Conclusion: This uncommon case reveals the possibility of the localization of malignant cells within bone metaplasia of intraocular ossification in an enucleated blind painful eye. From a practical point of view, a careful systematic histopathological examination of all resected tissues in patients with a history of malignant neoplastic pathology is necessary to confirm the diagnosis and exclude occult malignancies.
\end{abstract}

Keywords: Intraocular heterotopic ossification, Extramedullary hematopoiesis, Small lymphocytic lymphoma

\section{Background}

The presence of bone marrow within heterotopic ossification (HO) has been reported only a few times in the literature, and reports of finding hematological malignancies within the same bone marrow are even rarer. This uncommon case reveals the possibility of localization of malignant cells within bone metaplasia and we want to highlight the importance of a systematic histopathological examination of all resected tissue

\footnotetext{
*Correspondence: alfr.borgia@gmail.com

${ }^{1}$ Humanitas University, Department of Biomedical Sciences, Via Rita Levi Montalcini 4, 20090 Pieve Emanuele - Milan, Italy

Full list of author information is available at the end of the article
}

in patients with a history of malignant neoplastic pathology.

\section{Case presentation}

We report a case of true trilineage hematopoiesis in an excised area of $\mathrm{HO}$ from an enucleated blind painful eye.

A 70-year-old Caucasian man presented with a blind painful right eye to our ophthalmology department to evaluate enucleation bulbi. He had a history of a blunt trauma injury to his right eye that occurred 49 years ago, and he subsequently experienced hyphema, vitreous hemorrhages, and traumatic cataract. Over the past 10 years, he experienced episodes of ocular pain phthisis

(c) The Author(s). 2020 Open Access This article is licensed under a Creative Commons Attribution 4.0 International License, which permits use, sharing, adaptation, distribution and reproduction in any medium or format, as long as you give appropriate credit to the original author(s) and the source, provide a link to the Creative Commons licence, and indicate if changes were made. The images or other third party material in this article are included in the article's Creative Commons licence, unless indicated otherwise in a credit line to the material. If material is not included in the article's Creative Commons licence and your intended use is not permitted by statutory regulation or exceeds the permitted use, you will need to obtain permission directly from the copyright holder. To view a copy of this licence, visit http://creativecommons.org/licenses/by/4.0/. The Creative Commons Public Domain Dedication waiver (http://creativecommons.org/publicdomain/zero/1.0/) applies to the data made available in this article, unless otherwise stated in a credit line to the data. 
bulbi associated with trigeminal neuralgia. A slit lamp examination of his right eye showed band keratopathy and seclusion pupillae, with a brunescent traumatic cataract. A funduscopic examination of his right eye was not executable due to media opacity. His left eye was normal without any kind of lesions and had an uncorrected visual acuity (UCVA) of 20/20. A right eye ultrasound B-scan examination showed a phthisic eye, with complete retinal detachment, and hyperechogenic tissues with an acoustic shadowing due to calcification projected into the orbital tissue. For that reason, the clinicians decided to perform the enucleation of his right eye. His past medical history was positive for asymptomatic lymphoplasmacytic lymphoma associated with immunoglobulin M (IgM) monoclonal peak diagnosed 12 years before enucleation. At the onset, neither lymphadenopathies nor hepatosplenomegaly were described, and $20 \%$ bone marrow infiltration was documented. Our patient was periodically followed up without any treatment with evidence of a slow progressive disease, which did not require treatment up until now. Prior to the enucleation, magnetic resonance imaging (MRI) of his brain was performed to study a possible trigeminal neuralgia and was normal without any cerebral lesions.

The eyeball was removed and marked fibrosis with places of osseous metamorphism was noticed macroscopically. A histopathologic examination revealed diffusive fibrotic and calcified uveo-scleral flaps, with widespread bone metaplasia with hematopoietic marrow, mixed with retinal fragments with atrophic areas alternating with hyperplastic aspects and blood clots (Fig. 1a).

A further typing showed the presence of intertrabecular infiltration in the metaplastic bone marrow of nonHodgkin B lymphoma, with small lymphocytes, with similar characteristics to the already known disease. Immunostaining was positive for CD20, CD3, CD10, CD43, CD23, CD138, S100 GFAP, MelanA, and Ki-67 (Fig. 1b-c).

\section{Discussion}

Heterotopic bone formation, also known as $\mathrm{HO}$, is the unusual growth of bone outside the skeleton [1].

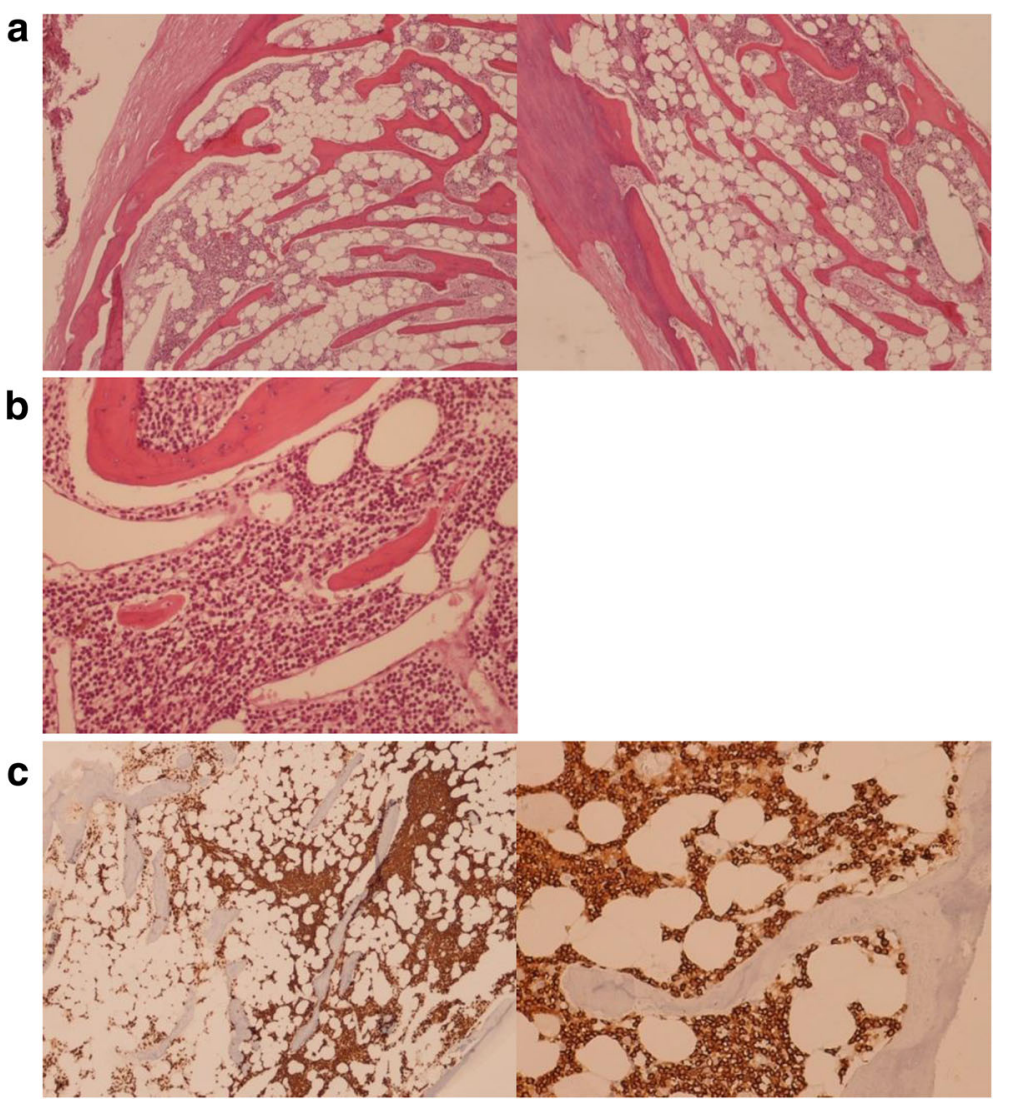

Fig. 1 a Calcified and ossified sclera flap, with bone trabeculae and intertrabecular spaces inhabited by adipose and hematopoietic medullary elements. There are areas more densely cellulated and occupied by small round cells with little lymphoid-looking cytoplasm ( $E E=H e m a t o x y l i n$ and Eosin (H\&E) $\times 10$ after decalcification treatment). b Homogeneous, small-sized lymphoid cells occupying the entire intertrabecular space ( $E E=$ Hematoxylin and Eosin $(H \& E) \times 40$ after descaling treatment). c Immunohistochemical staining with CD20 demonstrates the B lymphoid differentiation of the neoplastic population, occupying the medullary intertrabecular spaces of the newly formed metaplastic bone 
Heterotopic secondary ossification is usually seen in structures, such as muscles and tissues adjacent to the bone, after musculoskeletal injury or central nervous system or spinal cord trauma [1]. Less commonly encountered sites of heterotopic secondary ossification are in the mesentery, gastrointestinal tract, abdominal incisions and wounds, the walls of blood vessels, the kidneys, the uterus, and the eye $[2,3]$.

Intraocular ossification is a rare type of metaplasia that can occur after long-standing retinal detachment, some intraocular tumors, chronic inflammation, or eyeball trauma [4]. The incidence of intraocular ossification described in the literature of studies performed on enucleated eyes is up to $18 \%$; however, there are unpublished studies that report an occurrence rate higher than $38 \%$ $[5,6]$. This condition tends to develop very slowly. Choroidal ossification could be histopathologically traced approximately a year after a traumatic event, whereas it needs $10-20$ years to be radiologically identifiable $[7,8]$.

The pathogenic mechanism underlying intraocular ossification is not completely understood $[5,6,9]$. It seems that the base of intraocular bone formation is metaplastic retinal pigment epithelium (RPE) cells, which after a traumatic and inflammatory stimulus undergo osteoblastic and fibroblastic differentiation. This hypothesis is supported by the frequent observation of islands of RPE cells trapped in the newly formed bone [10].

The presence of bone marrow within $\mathrm{HO}$ has been reported only a handful of times in the literature; moreover, the finding of hematological malignancies within the same marrow has been described a few times, as in the case of the formation of myeloma found inside a heterotopic bone marrow in the aortic wall, and in bone metaplasia of a surgical scar [11-13]. This is possibly the first description of true trilineage hematological malignancy in intraocular $\mathrm{HO}$ in the literature.

Small lymphocytic lymphoma (SLL) is a non-Hodgkin lymphoma affecting the B lymphocytes of the immune system [14]. SLL often involves the bone marrow, which is why cancer cells have been found within intraocular ossification containing true hematopoietic tissue [15].

\section{Conclusions}

This rare case reveals the possibility of localization of malignant cells in true trilineage hematopoietic tissue within $\mathrm{HO}$ in an enucleated blind painful eye. In managing a painful blind eye, we must subject all enucleated specimens to a systematic histopathological examination, to confirm the diagnosis and exclude a hidden intraocular malignancy.

\section{Abbreviations}

SLL: Small lymphocytic lymphoma; HO: Heterotopic ossification; RPE: Retinal pigment epithelium

\section{Acknowledgements}

Not applicable.

\section{Authors' contributions}

$A B$ and $A D$ contributed to conception and design. SM, MB, and PV contributed to data acquisition. All authors contributed to interpretation of data; all authors drafted the article and approved its final version.

\section{Funding}

No funding was obtained for this study.

Availability of data and materials

All data supporting our findings are provided in the manuscript.

\section{Ethics approval and consent to participate}

The local ethics committee ruled that no formal ethics approval was required in this particular case.

\section{Consent for publication}

Written informed consent was obtained from the patient for publication of this case report and any accompanying images. A copy of the written consent is available for review by the Editor-in-Chief of this journal. The patient consented to the submission of the case report to the journal.

\section{Competing interests}

All other authors have no financial relationships to disclose. The authors declare that they have no competing interests.

\section{Author details}

${ }^{1}$ Humanitas University, Department of Biomedical Sciences, Via Rita Levi Montalcini 4, 20090 Pieve Emanuele - Milan, Italy. ${ }^{2}$ Humanitas Clinical and Research Center - IRCCS, Via Manzoni 56, 20089 Rozzano (Mi), Italy.

Received: 13 April 2020 Accepted: 1 June 2020

Published online: 08 July 2020

References

1. Haque S, Eisen RN, West AB, Shehab D, Elgazzar AH, Collier BD. Heterotopic ossification. J Nucl Med. 2002;43(3):346-53. Available from: http://www.ncbi. nlm.nih.gov/pubmed/8757473. Cited 9 Feb 2020.

2. Reardon MJ, Tillou A, Mody DR, Reardon PR. Heterotopic calcification in abdominal wounds. Am J Surg. 1997;173(2):145-7.

3. Haque S, Eisen RN, West A. Heterotopic bone formation in the gastrointestinal tract. Arch Pathol Lab Med. 1996;120(7):666-70.

4. Duke-Elder S. Disease of the uveal tract. In: Diseases of the uveal tract System of ophthalmology vol 9; 1966. p. 740-7. Available from: https://ci.nii. ac.jp/naid/10022618406/. Cited 9 Feb 2020.

5. Vemuganti GK, Honavar SG, Jalali S. Intraocular osseous metaplasia. A clinico-pathological study. Indian J Ophthalmol. 2002;50(3):183.

6. Finkelstein EM, Boniuk M. Intraocular ossification and hematopoiesis. Am J Ophthalmol. 1969;68(4):683-90. Available from: http://www.ncbi.nlm.nih. gov/pubmed/4981081. Cited 9 Feb 2020.

7. Zografos L, Uffer S, Girard-Othein BCh. Tumeurs osseoses de la choroide. In: Zografos $L$ (ed). Tumeurs intraoculaires. Paris: Masson; 2002. p. 335-50.

8. Munteanu M, Munteanu G, Giuri S, Zolog I, Motoc AGM. Ossification of the choroid: three clinical cases and literature review of the pathogenesis of intraocular ossification. Rom J Morphol Embryol. 2013;54(3):871-7. Available from: http://www.rjme.ro/. Cited 24 May 2020.

9. Lawson BM, Reddy SG, Jody NM. Extensive intraocular osseous metaplasia with bone marrow formation. JAMA Ophthalmol. 2018;136(8):e182377 https://doi.org/10.1001/jamaophthalmol.2018.2377.

10. Yoon YD, Aaberg TM, Wojno TH, Grossniklaus HE. Osseous metaplasia in proliferative vitreoretinopathy. Am J Ophthalmol. 1998;125(4):558-9. Available from: http://www.ncbi.n/m.nih.gov/pubmed/9559746. Cited 9 Feb 2020.

11. Elliott K, Fitzsimons DW, editors. Ciba Foundation Symposium 11 - Hard Tissue Growth, Repair and Remineralization. Chichester: Wiley; 1973. p. 16979. (Novartis Foundation Symposia; vol. 11). Available from: http://doi.wiley. com/10.1002/9780470719947. Cited 24 May 2020.

12. Toyran S, Lin AY, Edward DP. Expression of growth differentiation factor-5 and bone morphogenic protein-7 in intraocular osseous metaplasia. Br J 
Ophthalmol. 2005;89:885-90. Available from: http://bjo.bmj.com/. Cited 9 Feb 2020.

13. Udoji WC, Krohn NJ. Myelofibrosis and myeloma in heterotopic bone marrow. Arch Pathol Lab Med. 1979;103(6):315-6. Available from: http:// www.ncbi.nlm.nih.gov/pubmed/582271. Cited 9 Feb 2020.

14. Zelenetz AD, Gordon LI, Wierda WG, Abramson JS, Advani RH, Andreadis CB, et al. Chronic lymphocytic leukemia/small lymphocytic lymphoma, version 1.2015. J Natl Compr Cancer Netw. 2015;13(3):326-62.

15. Forest F, Molina L, Stefani L, Peoc'h M. Marginal zone B-cell lymphoma in true trilineage haematopoietic tissue within heterotopic ossification of a surgical scar. J Clin Pathol. 2012;65:1055-6. Available from: http://www.ncbi. nlm.nih.gov/pubmed/22798554. Cited 9 Feb 2020.

\section{Publisher's Note}

Springer Nature remains neutral with regard to jurisdictional claims in published maps and institutional affiliations.

Ready to submit your research? Choose BMC and benefit from:

- fast, convenient online submission

- thorough peer review by experienced researchers in your field

- rapid publication on acceptance

- support for research data, including large and complex data types

- gold Open Access which fosters wider collaboration and increased citations

- maximum visibility for your research: over $100 \mathrm{M}$ website views per year

At BMC, research is always in progress.

Learn more biomedcentral.com/submissions 